\title{
Feeding systems and food intake by housed dairy cows
}

\section{By J. A. Bines, National Institute for Research in Dairying, Shinfield, Reading $R G_{2} g A T$}

The development of the metabolizable energy (ME) system has greatly increased our knowledge of the energy value of feeds, the requirement of the cow for energy and the likely milk yield response to increments of energy (feed) at different stages of lactation. It is thus possible to treat the cow as an individual and allocate food according to her production potential. To do so requires the regular recording of each cow's performance, regular adjustment of diets and extensive investment in the equipment required to feed cows individually. Such a system is only likely to be used where:

(1) herds are small and recording yield or adjusting feeding will not require a great deal of time, or in larger herds where extensive use is made of electronic recording and computerized management aids;

(2) there is a wide spread of calving dates in herds which are not large enough to group;

(3) where very high levels of concentrates are given;

(4) when forage supplies are severely restricted.

Frequently, such a system does not involve ad lib. access to food and the amount of food given is below the appetite capacity of the animal. Where animals are housed and fed individually ad lib., daily dry matter (DM) intakes are similar to those of cows fed individually, but housed in groups (J. A. Bines, unpublished results).

Increasingly, herds do not fit into the previously-described categories, and the need to use labour efficiently has resulted in the widespread adoption of group housing of cows with group-feeding of at least the forage component of the diet and often of some or all the concentrate components as well. Where forage is available ad lib., the milk yield response to additional concentrates will be less than where forage intake is fixed due to the widely recognized substitution effect, i.e. the reduction in forage $\mathrm{DM}$ intake per unit increase in concentrate DM consumed. Under such feeding systems, the cow is allowed to express her potential up to the limitations imposed by the diet. Intake under these circumstances is determined by characteristics of the cows, of the forages and of the concentrates and by the feeding system (i.e. method of food allocation) in use. This paper is concerned primarily with the effects of feeding system on intake; characteristics of cows and food may have important interactions with the system. 


\section{Characteristics of the cow}

As has been pointed out in detail elsewhere (Bines, 1979, 1984), the size of cow and stage of lactation have greater influences on the amount of food eaten by the cow, than does her milk yield at any particular time. DM intake increases by about $1 \mathrm{~kg} / \mathrm{d}$ per $50 \mathrm{~kg}$ increase in live weight or per $10 \mathrm{~kg}$ increase in milk yield. It is difficult to relate intake at any stage of lactation to the performance of the cow at the same time. Indeed, in early lactation, for example, milk yield can be very high at a time when intake is notably depressed. Various approaches have been used to overcome this problem in developing intake-prediction equations (Bines, 1984). One solution which is not difficult to handle, is to assume that the form of the intake curve is similar to that of the lactation curve and analyse it by use of Wood's ( 1967 ) equation. This is discussed in more detail in Bines ( 1984 ).

\section{Characteristics of the forage}

These consist essentially of the species, the stage of maturity at harvest and the form in which fed (fresh, dried or ensiled). Comparisons are difficult because confounding between two or more of these characteristics often exists. In general terms, intakes of leguminous species are often greater than those of grass and related species. Within a species, stage of maturity at harvest has a major influence on digestibility and thereby on intake of forage. On average, intake rises by about $0.15 \mathrm{~kg} \mathrm{DM} / \mathrm{unit}$ increase in D value (in vitro digestible organic matter in the $\mathrm{DM}$ ) of the forage (Thomas, 1980). The effect of digestibility on intake may be more marked in early lactation than later on (Table 1). Various forms of physical or chemical treatment of forages of low digestibility are available to enhance their intake (Bines, 1984 ). Until now, these have not been widely used in the feeding of dairy cows, although they may become economically more attractive in the future to lower the costs of milk production.

The effect on intake of the form in which forage is given involves essentially a comparison of different methods of conservation since fresh and conserved forages are rarely in competition with each other under UK management systems.

Table I. Intakes of early and late cut silages ( $D$ values 68 and 62 respectively) at two stages of lactation by heifers given three levels of concentrate at a flat rate (R. H. Phipps and F. A. Bines, unpublished results)

\begin{tabular}{|c|c|c|c|c|}
\hline \multirow[b]{3}{*}{ Level of concentrate $(\mathrm{kg} / \mathrm{d})$} & \multicolumn{4}{|c|}{ Silage DM intake $(\mathrm{kg} / \mathrm{d})$} \\
\hline & \multicolumn{2}{|c|}{ Weeks I-10 } & \multicolumn{2}{|c|}{ Weeks 11-20 } \\
\hline & Early & Late & Early & Late \\
\hline 50 & 6.9 & $5 \cdot 0$ & $7 \cdot 4$ & 6.8 \\
\hline $7 \cdot 5$ & $5 \cdot 6$ & $4 \cdot 4$ & $5 \cdot 8$ & $6 \cdot 2$ \\
\hline 10.0 & 4.9 & $4 \cdot 3$ & $4 \cdot 9$ & $5 \cdot 2$ \\
\hline
\end{tabular}

$D$ value, in vitro digestible organic matter in the dry matter. 
Table 2. Silage intake in relation to hay, for milk production (Demarquilly $\&$ Dulphy, 1977)

$\begin{array}{ccc}\begin{array}{c}\text { Silage DM } \\ (\mathrm{g} / \mathrm{kg})\end{array} & \begin{array}{c}\text { Silage DMI } \\ \text { (hay 100) }\end{array} & \begin{array}{c}\text { Milk yield (FCM) } \\ \text { (hay I00) }\end{array} \\ 250 & 81 & 98 \\ 340 & 87 & 100 \\ 490 & 103 & 103\end{array}$

DM, dry matter; DMI, dry matter intake; FCM, fat corrected milk ( $4 \circ \mathrm{g}$ fat $/ \mathrm{kg}$ milk).

Artificial drying of young highly-digestible grass and other crops provides an attractive food for dairy cows. It is eaten in large amounts and can sustain substantial milk yields without supplementation (Thomas, 1980). Unfortunately, its high cost relative to other forms of conserved forage means that it is only used in certain very specialized circumstances. Where hay and silage have been made from similar crops cut at the same stage of maturity, intakes of silages are generally lower than those of hays. The reasons for this are not clear, but appear to relate to the DM content of the silages and probably also, directly or indirectly, to fermentation characteristics (Table 2). Wilting before ensiling will raise the DM content of the silage and often, also, intake. However, this does not result in a consistent effect on cow performance (Thomas, 1980). In contrast, use of an additive usually raises both intake and milk yield (Tyrrel \& Reid, 1967 ).

\section{Characteristics of concentrates}

There is not a great deal of information about the effect of concentrate composition on food intake. The best-established relationship is the tendency for some protein concentrates to stimulate silage intake (Castle \& Watson, 1976; Gordon, 1979). The mechanism of this effect is not clear but probably relates to the form, rather than the amount of protein in the diet. High-quality dried forages, especially when ground and pelleted, probably act in a similar way (Tayler \& Aston, 1976).

Many typical dairy concentrates inhibit forage intake, i.e. they substitute for forage rather than supplement it. This probably results from depression of fibre digestion in the rumen by the products of digestion of the concentrate, especially those derived from the starchy constitutents. This being so, it should be possible to reduce this problem by replacing the energy of the starchy ingredients by other readily-digestible sources of energy (e.g. fat or cellulose). It has been shown that such changes can raise forage DM intakes by about $\mathrm{I} \mathrm{kg} / \mathrm{d}$ (Thomas $e t$ al. 1984 ; J. A. Bines and J. D. Sutton, unpublished results). Nevertheless, depression of forage intake by increments of concentrates did not differ between concentrate types (J. A. Bines and J. D. Sutton, unpublished results).

\section{Methods of feeding}

(a) Forages. The method used for feeding forages to cattle may play a major role in determining the amount eaten. There is some evidence (Coppock et al. 1972; 
Table 3. Effect of length of feed trough on time spent feeding and feed intake of cows with continuous access to a complete diet (Friend et al. 1977)

Time at trough $(\mathrm{h})$

Proportion of time utilized Intake ( $\mathrm{kg}$ fresh wt/d)
Trough length per cow $(\mathrm{m})$

$\begin{array}{ccccc}0.5 & 0.4 & 0.3 & 0.2 & 0.1 \\ 3.8 & 3.7 & 3.7 & 3.8 & 2.6 \\ 0.22 & 0.27 & 0.35 & 0.52 & 0.71 \\ 37.3 & 37.4 & 37.8 & 36.0 & 33.2\end{array}$

Phipps et al. 1983) that the mere act of feeding cattle in groups will raise intake compared with individual feeding. However, this can only come about where access to food is not limited. Three methods of forage allocation can be distinguished: ( $\mathrm{I}$ ) directly from a silage clamp; (2) from a trough (silage) or rack (hay); (3) as part of a complete diet (from a trough or feeding passage).

Where cows are feeding from a trough, rack or feeding passage, the forage will be in a loose form and prehension will not involve any effort in removing food from a compacted mass as is the case with feeding directly from a clamp. Under these circumstances it is clearly established that the length of the trough per cow is the major factor affecting intake. The size of this effect is illustrated in Table 3 . Clearly, in reducing trough length from 300 to $200 \mathrm{~mm} / \mathrm{cow}$, there is a reduction in the amount of food eaten although this is not apparent from the amount of time spent at the trough. A reduction below $200 \mathrm{~mm}$ results in a marked depression of both feeding time and food intake. The commonly recommended minimum width in the UK to avoid inhibition of intake is $240 \mathrm{~mm}$ where access is available throughout the $24 \mathrm{~h}$ period.

The compacted nature of silage in a clamp reduces the rate of eating by the cow. If maximum intakes are to be obtained, the cow will need to spend a greater amount of time eating and therefore a greater total face width will be required. It seems likely that compaction will be greater in wetter materials and in less-fibrous materials and also possibly in mixtures containing substantial amounts of clover. To ensure maximum forage intake, the minimum recommended width in the UK for feeding directly from a clamp is $300 \mathrm{~mm}$. Even so, we have recorded intakes of silage from a clamp which are $20 \%$ lower than those of similar cows eating from troughs (R. H. Phipps and J. A. Bines, unpublished results).

The use of complete diets is likely to increase forage intake where the acceptability of the forage is inherently low, i.e. low digestibility or poor fermentation. In one trial where a poor-quality lucerne (Medicago sativa) silage was given together with maize silage, sugar-beet pulp and concentrates, total DM intake was about $2 \mathrm{~kg}$ greater when the foods were given as a complete diet than when they were given separately (Phipps et al. 1984a). In the latter situation, the lucerne silage was invariably the first food to be refused in an experiment where the amounts of the other dietary components were restricted in order to maintain a constant composition of the total ration eaten. The concentrate content of this mix 
Table 4. Reduction in intake of forage per unit of additional concentrate $(\mathrm{kg} / \mathrm{kg}$ DM or OM given to milking cows

$\begin{array}{lcl}\text { Poor hay } & 0.17 & \text { Marsh et al. (1971) } \\ \text { Poor grass silage } & 0.32 & \text { R. H. Phipps and J. A. Bines (unpublished results) } \\ \text { Lucerne (Medicago sativa) hay } & 0.44 & \text { Ward \& Kelly (1969) } \\ \text { Grazing } & 0.55 & \text { Leaver } \text { et al. (1968) } \\ \text { Dried grass } & 0.55 & \text { Marsh } \text { et al. (1971) } \\ \text { Zero grazing } & 0.6-0.7 & \text { Taparia \& Davey (1970) } \\ \text { Medium grass hay } & 0.63 & \text { J. A. Bines and J. D. Sutton (unpublished results) } \\ \text { Maize silage } & 0.63 & \text { Phipps \& Cramp (1978) } \\ \text { Good grass silage } & 0.68 & \text { R. H. Phipps and J. A. Bines (unpublished results) } \\ \text { Lucerne wafers } & 0.78 & \text { Bath et al. (1974) } \\ \text { Spring grass } & 1.00 & \text { Broster (1975) } \\ & & \end{array}$

was about $650-700 \mathrm{~g} / \mathrm{kg}$ and may also have contributed, in part, to the difference in intake. Other aspects of complete diet feeding are dealt with in the next section.

(b) Concentrates. The two important components of the feeding system with regard to the concentrate part of the diet, are the total amount given and the number of meals into which that daily allocation is divided. All feeding systems can be considered in these terms. In general, an increase in the total amount of concentrates given, or a decrease in the frequency of feeding will both generate a more extreme rumen environment (Sutton, $198 \mathrm{I}$ ) which will potentially depress fibre digestibility and hence forage intake.

The commonest management system is the feeding of concentrates in the milking parlour during milking and will therefore take place twice, or occasionally three times, per $\mathrm{d}$. Whether the concentrates are allocated to cows according to individual performance, or whether a flat-rate system of allocation is used is much less important than the total amount given to each cow. As the level of concentrate increases so the forage intake will decline. This decline will vary with the type of forage available and will be related, broadly, to the feeding value of the forage; this substitution effect is illustrated in Table 4. The rate of substitution declines with advancing lactation (Ekern, 1972; Bines, 1984) and may increase with increasing proportion of concentrates in the total diet (Østergaard, 1979). The latter effect may be responsible for the apparently-higher substitution rates in higher-yielding cows (Thomas, I980). Since, for most forages, the substitution rate is less than $\mathbf{I} \cdot 0$, it follows that increasing the amount of concentrates given will generally raise total food intake even though forage intake declines.

Where flat-rate feeding of concentrates has been compared with either fixed stepped rates or with feeding to yield, it has been concluded that cow performance is not adversely affected provided the forage is of good quality $(D>65)$ and is available ad lib. Under these circumstances, cows of higher potential are able to compensate for any deficiency in nutrient supply in the concentrates by eating more forage (Table 5). This may be only a partial compensation and may result in a reduced peak yield by the cow, but a large body of evidence suggests that this is 
Table 5. Relation between lactation yield and intake of forage by cows given concentrates at a flat rate (after Thomas, 1980)

\begin{tabular}{|c|c|c|}
\hline Lactation yield (1/year) & 7000 & 4946 \\
\hline DMI (kg): Silage & $10 \cdot 6$ & $8 \cdot 7$ \\
\hline Concentrate & $7 \cdot 1$ & $7 \cdot 1$ \\
\hline Total & 17.7 & 15.8 \\
\hline Live-wt change: weeks $4^{-22}(\mathrm{~kg})$ & $+7 \cdot 5$ & +15.6 \\
\hline
\end{tabular}

DMI, dry matter intake.

balanced by improved persistency so that total lactation performance is either

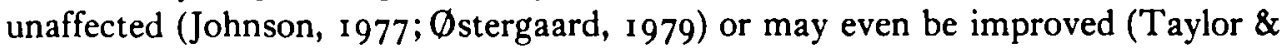
Leaver, 1984). Fuller accounts of flat-rate feeding have been published (Taylor, 1979; Bines, 1984).

Increasing the frequency of feeding concentrates, especially where the total daily allocation is large, may be expected to reduce or even eliminate extremes in the pattern of rumen fermentation (Sutton, $198 \mathrm{I}$ ). This is known to enhance the rate of fibre digestion in the rumen and should theoretically raise forage intake. Unfortunately, there is little experimental evidence to either prove or disprove this theory. Where large amounts of concentrates have been given at increased frequencies, forage availability has been restricted. Where forage has been available to appetite, the amounts of concentrates offered have generally been small (Gibson, 1984).

In practical terms, increased frequency of concentrate allocation is achieved in three ways:

(I) extra feeds between milkings either in a trough (which precludes control over each individual cow's intake) or by taking cows through the milking parlour;

(2) out-of-parlour concentrate dispensers;

(3) complete-diet feeding.

In the first of these, as indicated previously, there have been few trials where the level of concentrates has been high and forage was available ad lib. Where these two conditions were met (Kaufmann, 1976), the increase in forage intake was disappointingly small.

Out-of-parlour concentrate dispensers vary in the degree of sophistication. The older models gave selected cows unrestricted access to concentrates at any time of the day. More recently, computerized models enable each cow to be allocated an individual ration, the intake of which can be spread over four, six or more periods in the day. Regardless of the degree of control possible, there is little independent evidence of a marked improvement in forage intake resulting from the use of these machines (e.g. Gordon, 1984).

Increasing the frequency of feeding concentrates by the use of complete-diet techniques has not established clear intake advantages with conventional diets, although there may be an increase where higher levels of concentrates are used 
(Phipps et al. 1984a). Within the complete-diet system, however, variations in intake are likely to result from variations in composition of the complete diet. There is considerable difference of opinion on the need to group cows according to performance and provide a different complete diet for each group. Where a single diet is provided there is a risk that either the performance of high-yielders may be depressed, or that low-yielders will become overfat. The evidence from work on flat-rate feeding is that a change in the shape of the lactation curve of the high-yielders may allow them to adapt to possible underfeeding in early lactation. Overfatness in lower-yielders can only be overcome by removing them from the herd. Reducing the energy concentration of the complete diet as lactation progresses will result in a marked fall in intake and milk yield (Phipps et al. 1984b) although the diet will be used with greater efficiency.

\section{REFERENCES}

Bath, D. L., Gall, G. A. E. \& Ronning, M. (1974). Fournal of Dairy Science 57, I98-204.

Bines, J. A. (I979). In Feeding Strategy for the High-Yielding Dairy Cow, pp. 23-48 [W. H. Broster and H. Swan, editors]. Granada Press: St Albans, Herts.

Bines, J. A. (1984). Western Nutrition Conference, University of Alberta, pp. I66-1 82.

Broster, W. H. (1975). In Simplified Feeding for Milk and Beef, pp. $113^{-125}$. London: US Feed Grains Council.

Castle, M. E. \& Watson, J. N. (1976). Fournal of the British Grassland Society 31, $191-195$.

Coppock, C. E., Noller, C. H., Crowe, B. W., McLellon, C. D. \& Rhykerd, C. C. (1972). fournal of Dairy Science 55, 325-327.

Demarquilly, C. \& Dulphy, J. P. (1977). Proceedings of International Meeting on Animal Production from Temperate Grasslands, pp. 53-61 [B. Gilsenan, editor]. Dublin: Irish Grassland and Animal Production Association/An Foras Taluntais.

Ekern, A. (1972). Meldinger fra Norges Landbrukhøgskole 51, no. 32.

Friend, T. M., Polan, C. E. \& McGilliard, M. L. (1977). Journal of Dairy Science 60, 108-1 16.

Gibson, J. P. (1984). Animal Production 38, 181-189.

Gordon, F. J. (1979). Animal Production 28, I83-188.

Gordon, F. J. (1984). Animal Production 38, 520 .

Johnson, C. L. (1977). Fournal of Agricultural Science, Cambridge 88, 79-94.

Kaufmann, W. (1976). Livestock Production Science 3, 103-114.

Leaver, J. D., Campling, R. C. \& Holmes, W. (r 968). Dairy Science Abstracts 30, 355-36r.

Marsh, R., Curran, M. K. \& Campling, R. C. (1971). Animal Production 13, 107-1 16.

Østergaard, V. (1 979). National Institute for Animal Science, Copenhagen Bulletin no. 482.

Phipps, R. H., Bines, J. A. \& Cooper, A. (1983). Animal Production 36, 544 .

Phipps, R. H., Bines, J. A., Fulford, R. J. \& Weller, R. F. (1 $984 a$ ). Fournal of Agricultural Science, Cambridge 103, $171-180$.

Phipps, R. H., Bines, J. A., Weller, R. F. \& Thomas, J. (1984b). fournal of Agricultural Science, Cambridge 103, 323-331.

Phipps, R. H. \& Cramp, D. G. (1978). Fournal of the British Grassland Society 33, 19-22.

Sutton, J. D. (1981). Recent Advances in Animal Production - 1981, pp. 35-48 [W. Haresign, editor]. London: Butterworths.

Taparia, A. L. \& Davey, A. W. F. (1970). New Zealand fournal of Agricultural Research 13, 616-622.

Tayler, J. C. \& Aston, K. (1976). Animal Production 23, 197-209.

Taylor, K. (1979). Flat rate feeding of concentrates to dairy cows. Farm Management Service Report no. 20. Reading: Milk Marketing Board.

Taylor, W. \& Leaver, J. D. (1984). Animal Production 38, 521 . 
Thomas, C. (1980). In Feeding Strategies for Dairy Cows, pp. 8.1-8.14 [W. H. Broster, C. L. Johnson and J. C. Tayler, editors]. London: Agricultural Research Council.

Thomas, C., Aston, K., Daley, S. R. \& Hughes, M. (1984). Animal Production 38, 519.

Tyrrel, H. F. \& Reid, J. T. (1967). Proceedings of Cornell Nutrition Conference, Pp. 137-145. Ithaca: Cornell University.

Ward, G. M. \& Kelly, P. L. (1969). Fournal of Dairy Science 52, 101 7-1019.

Wood, P. D. P. (1967). Nature 216, 164-165. 